The Embattled Vote in America 



\title{
The Embattled Vote in America
}

From the Founding to the Present

\author{
ALLAN J. LICHTMAN
}

\section{II \\ III}

Harvard University Press

Cambridge, Massachusetts

London, England

2018 
Copyright (c) 2018 by the President and Fellows of Harvard College

All rights reserved

Printed in the United States of America

First printing

Library of Congress Cataloging-in-Publication Data

Names: Lichtman, Allan J., author.

Title: The embattled vote in America : from the founding to the present /

Allan J. Lichtman.

Description: Cambridge, Massachusetts : Harvard University Press, 2018. |

Includes bibliographical references and index.

Identifiers: LCCN 2018006882 | ISBN 9780674972360 (alk. paper)

Subjects: LCSH: Suffrage-United States-History.

Classification: LCC JK1846 .L53 2018 | DDC 324.6/20973-dc23

LC record available at https://lccn.loc.gov/2018006882

Jacket design: Tim Jones

Background artwork: Courtesy of Getty Images

Inset images: "The 'Gerrymander' Monster of Massachusetts," 1812, and "How the coloured voter is allowed to cast his ballot in a state where Democrats control the election," 1899, courtesy of the Library of Congress 
To my extraordinary family: Karyn, Sam and Kara, Steven, and Ronnie 
